\title{
The Effect of Winter Mountaineering Training on Athlete Success and Permanency of Learning
}

\author{
Burak Kural (Corresponding author) \\ Faculty of Sport Sciences, Trabzon University, Trabzon 61300, Turkey \\ E-mail: burakkural@trabzon.edu.tr \\ Selami Yüksek \\ Faculty of Sport Sciences, Trabzon University, Trabzon 61300, Turkey \\ E-mail: selami.yuksek@trabzon.edu.tr \\ Vedat Ayan \\ Faculty of Sport Sciences, Trabzon University, Trabzon 61300, Turkey \\ E-mail: vayan@trabzon.edu.tr
}

Received: November 5, 2021 Accepted: December 4, 2021

Published: December 31, 2021

doi:10.5296/jei.v7i3.19186 URL: https://doi.org/10.5296/jei.v7i3.19186

\begin{abstract}
Introduction and Purpose: The aim of this research is to examine the effects of athlete success and permanency of learning the winter mountaineering training given by the Turkish Mountaineering Federation. The research group consists of a total of 105 participants, 21 women $(20 \%)$ and 84 men $(80 \%)$ who attended the winter mountaineering training course organized by the Turkish Mountaineering Federation. Materials and Methods: In this study, quasi-experimental design was used in the research. A multiple-choice achievement test of 25 questions which includes knowledge and practice issues related to winter mountaineering education was prepared. The reliability analysis of the achievement test was made with the "ITEMAN" program. The pre-test-post-test data of the study were collected on 20-27 January 2019 on Zigana Mountain, and 4 weeks later, the permanency test data was collected on 28 February 2019 on Erciyes Mountain. In data analysis, for correlated samples (repeated measures) one-factor ANOVA and for repeated measurements two-factor ANOVA analyzes
\end{abstract}


were performed. Findings: There was a significant difference between the pre-test-post-tests-permanency test total, knowledge, and application scores of the athletes. It is seen that the achievement scores of male and female athletes before and after the training do not differ significantly. Results: According to the research results; It has seen that the winter mountaineering training given by the Turkish mountaineering federation has a positive effect on the knowledge and practice levels of the athletes and has an important contribution in the context of the permanency of learning. In addition, it was determined that the success scores of female athletes who received training were higher than male athletes.

Keywords: Winter mountaineering training, Athlete success, Permanency

\section{Introduction}

Mountaineering is the confrontation between the complex natural environment and oneself. The content of this sport includes climbing, spending time in nature, watching beautiful landscapes, struggle, risks, and difficulties. Because mountaineering is done in an environment which human needs are not considered. Mountaineering, which started as attempts to reach the highest point of large unclimbed mountains, is divided into sub-branches depending on whether the route is over rock, snow or ice or it is flat. These sub-branches consist of a number of sub-branches including summer mountaineering, winter mountaineering, traditional rock, ice, alpine climbing and sport climbing (Bashir \& Muthueleckuvan, 2018). Winter mountaineering involves climbing in runnels filled with snow and ice in winter conditions, covered with thin ice on rock, and mixed rods (a combination of rock, ice, and vegetation). For this reason, winter climbing is considered as a high-risk sport (Schoffl, Morrison, Schwarz, Schoffl, \& Kupper, 2010), and winter mountaineering involves encountering challenging conditions that require a high level of skill and a great will to succeed (UIAA, 2008). Winter mountaineering immerses the climber in a different world. There is a big difference between climbing on weekends by an amateur climber and winter mountaineering by a professional alpine climber. Even the subject of weather conditions can tell us the difference in the level of effort required to climb this winter. For example, in summer climbing, weather conditions are not very important. If the weather is bad, they may have the opportunity to cancel the climb and try again when the weather improves, or if the weather breaks the climb, the climbers can go back down the route and return home. However, good weather conditions are less likely in the winter, and climbers may find it difficult to climb despite the bad weather forecast.

If the weather deteriorates during the climb, returning from the route may turn into a risky situation due to route finding difficulties, avalanche, and cornice hazards (Graydon \& Hanson, 2005). Being different from summer mountaineering in harsh winter conditions, winter mountaineering requires various degrees of experience, ability, and technical knowledge to ensure safety (Bashir \& Muthueleckuvan, 2018). Having knowledge and experience about safety while climbing, rope descent, knot tying, safety of movement on the glacier, first aid, and most importantly, rock, snow and ice climbing technical tools and equipment is important for staying safe and healthy on the mountain (Graydon \& Hanson, 2005). Because in order to get out of a difficult situation while climbing, the climber must trust himself and those around 
him. Because self-rescue is often seen as the only option, given that the closest help is days away.

The realization of risky mountaineering activities, which require such technical knowledge and have too many rules, requires systematic and continuous training. In other words, mountaineering education is very important in terms of teaching people; to survive under difficult mountain conditions, to increase their self-confidence and to act consciously in life (Lai, Hsu, \& Wearing, 2016). Because with the training, the danger dimension in sports can be minimized when the development of the individual in the cognitive, affective, and psychomotor fields is reinforced with his experience (Demirhan, 1995). After the training, it shows the physical and spiritual limits of the person, allows him to struggle with his own mind, and also introduces the reality of life and the world (Korenjak, 2017; Mummery, 2003). In addition to self-confidence, it also aims to reveal the characteristics and leadership spirit that the person is not aware of (Kurt, Bayazit, Keskin, \& Taşkıran 2018). Human-induced risks (Demirhan, 2003); for example, the persons knowledge and skills increase and his/her conditions such as lack of attitude, wrong way of acting, lack of material quite develop. Most importantly, having a high technical knowledge and skill after the training ensures that the climber and those around him are safe and healthy in case of encountering difficult conditions.

There are many models and methods developed and applied in order to achieve permanent and effective learning in sports education. These methods are traditional (direct) and cooperative learning methods (Mohr, Townsend, \& Pritchard, 2006; Siedentop, 2011). All these methods have both positive and negative aspects. However, in all these methods, "how to reach the determined targets at the highest level?" An answer is sought for the question, and the strategies, methods and techniques applied are examined in every aspect and they work on methods that will contribute to the development of human beings with different dimensions (Mirzeolu, Efe, \& Dogan, 2005). In this study, with the winter mountaineering training given by the trainers, it is thought to achieve the objectives of learning the knowledge and skills on subjects such as winter mountaineering specific materials, camping and hiking information, safety in snow and ice, route information, avalanche information, and also ensuring permanency in learning after the training.

In this context, the aim of this research is to examine the effects of winter mountaineering training given by the Turkish Mountaineering Federation on athlete success and the permanency of learning. For this purpose, the sub-problems of the research were determined as follows:

$\checkmark \quad$ Is there a difference between the pre-test, post-test, and permanency test success scores of the athletes who take winter mountaineering training?

Is there a significant difference between the pre-test, post-test and permanency test knowledge scores of the athletes who take winter mountaineering training?

Is there a significant difference between the pre-test, post-test and permanency test practice scores of the athletes who take winter mountaineering training? 
Is there a significant difference in gender between the pre-test, post-test and permanency test success scores of the athletes who take winter mountaineering training?

\section{Method}

\subsection{Research Model}

The research was carried out in a single-group quasi-experimental design model with pre-test-post-test practices. In this design, the effect of the experimental procedure is tested with a study on a single group. The effectiveness of the practices is researched on a single group by making both pre-experiment and post-experiment measurements (Buyukozturk, 2016). The experimental model of the study is shown in Table 1.

Table 1. Single-group pretest-posttest quasi-experimental model of the research

\begin{tabular}{|l|l|l|l|l|l|}
\hline \multirow{2}{*}{ Groups } & Pre-implementation & $\begin{array}{l}\text { Implementation } \\
\text { process }\end{array}$ & \multicolumn{2}{|c|}{ Post-implementation } \\
\cline { 2 - 6 } & Pre-test & $(1$ week $)$ & Post-test & Duration & Permanency Test \\
\hline $\begin{array}{l}\text { The group in which the } \\
\text { training programs are applied }\end{array}$ & Achievement test & $\begin{array}{l}\text { Training and } \\
\text { practice }\end{array}$ & Achievement test & 4 weeks & Achievement test \\
\hline
\end{tabular}

\subsection{Research Group}

The research group consists of in total 105 participants, 21 women (20\%) and 84 men (80\%), who attended the winter mountaineering training course organized by the Turkish Mountaineering Federation. The demographic characteristics of the participants are shown in.

Table 2. Demographic characteristics of the participants in the research group

\begin{tabular}{|l|l|l|l|}
\hline Variable & Categories & $\mathbf{N}$ & $\mathbf{\%}$ \\
\hline \multirow{4}{*}{ Gender } & Female & 21 & 20.0 \\
\cline { 2 - 4 } & Male & 84 & 80.0 \\
\hline \multirow{4}{*}{ Sarital status } & Single & 70 & 66.7 \\
\cline { 2 - 4 } & Married & 35 & 33.3 \\
\hline \multirow{4}{*}{ Profession } & High school & 30 & 28.6 \\
\cline { 2 - 4 } & License & 61 & 58.1 \\
\cline { 2 - 4 } & Postgraduate & 14 & 13.3 \\
\hline & Student & 34 & 32.4 \\
\cline { 2 - 4 } & Public sector & 46 & 43.8 \\
\cline { 2 - 4 } & Private sector & 25 & 23.8 \\
\hline
\end{tabular}




\section{Macrothink}

According to Table 2, 70 (66.7\%) of the athletes participating in the winter mountaineering training course are single and $35(33.3 \%)$ are married. Considering their educational status, it is seen that $30(28.6 \%)$ of the participants have high school education, $61(58.1 \%)$ have undergraduate education and $14(13.3 \%)$ have postgraduate education. In terms of profession, $34(32.4 \%)$ are students, $46(43.8 \%)$ are working in the public sector and $25(23.8 \%)$ are working in the private sector.

\subsection{Data Collection Tool}

An achievement test was used to collect the research data. This test was developed to determine the effects of winter mountaineering training on the success of the athletes and the permanency of learning. The achievement test consists of two parts. In the first section, there is a personal information form. In the second part, there are information and practice questions about winter mountaineering training. The following process was followed in the preparation, development, and validity-reliability study of this test.

In the preparation of the achievement test (measurement tool), winter mountaineering training subjects included in the education legislation of the Turkish Mountaineering Federation were examined (TDF, 2019). Then, the acquisitions related to each topic and the time allocated for the teaching of these acquisitions were determined (Table 3). Evaluation questions used by different coaches in previous trainings were examined. In addition, the subjects that the athletes learned in the previous training and their readiness were also taken into consideration. As a result of all these evaluations, an achievement test was created with the understanding of preparing at least three times as many questions for each of the determined acquisitions (Turgut \& Baykul, 2014). 
Table 3. The acquisitions related to each topic in the research and the time allocated to the teaching of these acquisitions

\begin{tabular}{|c|c|c|c|}
\hline \multirow{2}{*}{ Topic title } & \multirow{2}{*}{ Gains } & \multicolumn{2}{|c|}{ Duration(hours) } \\
\hline & & Theory & Practical \\
\hline $\begin{array}{l}\text { Terrain qualities in winter } \\
\text { mountaineering. }\end{array}$ & $\begin{array}{l}\text { Knows the features and types of snow (ridges, snow-ice lanes, } \\
\text { cornices). }\end{array}$ & 1 & - \\
\hline Equipment knowledge. & $\begin{array}{l}\text { Recognizes personal, camping, and technical equipment for } \\
\text { winter mountaineering. }\end{array}$ & 3 & - \\
\hline Trekking knowledge. & $\begin{array}{l}\text { Knows the choice of camping area, setting up tents and } \\
\text { landscaping in winter mountaineering. It can make the } \\
\text { snow cave. }\end{array}$ & 1 & 7 \\
\hline Hiking knowledge and technique. & $\begin{array}{l}\text { Knows and applies the knowledge and technique of } \\
\text { making tracks in the snow, walking with crampons. }\end{array}$ & 2 & 10 \\
\hline Safe movement on snow and ice. & Knows and applies the use of pickaxes and falls. & 2 & 8 \\
\hline Belay in snow and ice. & Knows and applies safety systems and safety in snow. & 2 & 8 \\
\hline $\begin{array}{l}\text { Planning an activity in winter } \\
\text { mountaineering. }\end{array}$ & $\begin{array}{l}\text { Choosing a route on the mountain in winter knows the } \\
\text { difficulty levels of the route. }\end{array}$ & 1 & - \\
\hline Establishing routes and navigating. & Knows how to find routes in snowy terrain and use navigation. & 1 & 3 \\
\hline $\begin{array}{l}\text { Nutrition and fluid intake } \\
\text { information. }\end{array}$ & Knows nutrition and water supply in the mountain in winter. & 1 & - \\
\hline $\begin{array}{l}\text { Avalanche knowledge and ability } \\
\text { to make avalanche tests. }\end{array}$ & $\begin{array}{l}\text { Knows how to pass avalanche tracks and avalanche tracks } \\
\text { safely. Applies avalanche tests. }\end{array}$ & 2 & 4 \\
\hline $\begin{array}{l}\text { First aid information on the } \\
\text { mountain. }\end{array}$ & $\begin{array}{l}\text { Recognizes and knows the treatment of mountain diseases } \\
\text { (Hypothermia, frostbite, snow blindness, dehydration). }\end{array}$ & 3 & - \\
\hline Mountaineering training knowledge. & Knowledge of training, physiology, and injury prevention. & 1 & - \\
\hline
\end{tabular}

The accuracy of the information in the achievement test and its suitability for the achievements were carried out with three mountaineering trainers', an education scientist', and an assessment and evaluation instructor's opinion. After the necessary corrections were made in line with the expert opinions, the validity and reliability study were applied to 30 mountaineers who had winter mountaineering training. According to the Iteman analysis results, the item difficulty of the test was found to be in the range of 0.24-0.90, the difficulty level of the items was between 0.33 and 0.81 , and the discrimination index was between $0.22-0.62$. In addition, the reliability of the test was found as 0.68 . Of these questions, 5 questions with discrimination power of less than or incompatible with the program were excluded from the test. As a result of these processes, a four-choice multiple choice achievement test consisting of 25 questions, 15 of which is knowledge and 10 of which is practice, was obtained. In the evaluation of the test, " 1 " point was given for each correct answer, and " 0 " point was given for wrong and empty answers. The highest score that can be obtained from this test is " 25 ". 


\subsection{Data Collection}

The achievement test, which was developed to measure the effects on the success of the athletes and the permanency of learning, was applied to the athletes as a pre-test-post-test before and after the winter mountaineering training and the data were obtained. 4 weeks after the winter mountaineering training was completed, the success test was applied to the same athletes again as a permanency test; and the data were obtained. The pre-test-post-test data of the study were collected on 20-27 January 2019 in Zigana Mountain, and the permanency test data were collected in Erciyes Mountain on 28 February 2019.

\subsection{Data Analysis}

In order to decide which techniques will be used in the analysis of the data within the scope of the research, the normality test was performed. In order to determine whether the data showed a normal distribution, skewness and kurtosis values and the results of the Shapiro-Wilk test were examined. The fact that the skewness and kurtosis coefficients are close to 0 within the limits of \pm 1 is considered as evidence for the existence of a normal distribution (Cokluk, Şekercioğlu, \& Büyüköztürk, 2016). One-factor ANOVA for associated samples (repeated measures) and then for repeated measurements ANOVA analyzes were performed. The purpose of the single-factor ANOVA analysis for repeated measures is to test whether the mean scores of two or more related measurement sets differ significantly from each other (Büyüköztürk, 2014). For the analysis, it was first tested whether the necessary assumptions. In order to determine the difference between the measurements, the Bonferroni test was performed in pairwise comparison.

\section{Findings}

In this part of the research, findings obtained by solving sub-problems were presented in tables and graphics with various statistical methods, and research findings were interpreted.

Among the total scores of the pre-test, post-test and permanency test of the athletes who took winter mountaineering training for repeated measurements to determine if there is a significant difference ANOVA test was performed and test results are shown in Table 4.

Table 4. Pre-test-post-test-permanency test total scores of the research group related ANOVA results

\begin{tabular}{|l|l|l|l|l|l|l|l|}
\hline Source of Variation & Sum of Squares & $\mathrm{df}$ & Mean Squares & $\mathrm{F}$ & $\mathrm{p}$ & $\eta^{2}$ & S.D. Bonferroni \\
\hline Between groups & & & & & & & \\
\hline Measurement & 7919.930 & 1.866 & 4244.742 & 447.631 & $.000^{*}$ & .811 & $\begin{array}{l}\text { Pre-post-test; } \\
\text { Pre-perm.test }\end{array}$ \\
\hline Error & 1840.070 & 194.045 & 9.483 & & & & \\
\hline Total & 9760 & 195.97 & & & & & \\
\hline
\end{tabular}

Note. ${ }^{*} \mathrm{p}<0.05 ; * * \mathrm{p}<0.01$. 


\section{Macrothink}

According to Table 4, as a result of the analysis, the homogeneity condition of the variances of the differences between the scores could not be met (Sphericity assumption) by looking at the epsilon value $(\varepsilon<0.75)$ Analysis of variance including Greenhouse-Geisser correction was performed. According to the results of this analysis, between the athletes' pretest-posttest-permanency test there was a significant difference in the scores $\left(\mathrm{F}_{1.866-194.045}=\right.$ 447.631, $\mathrm{p}<.001)$.

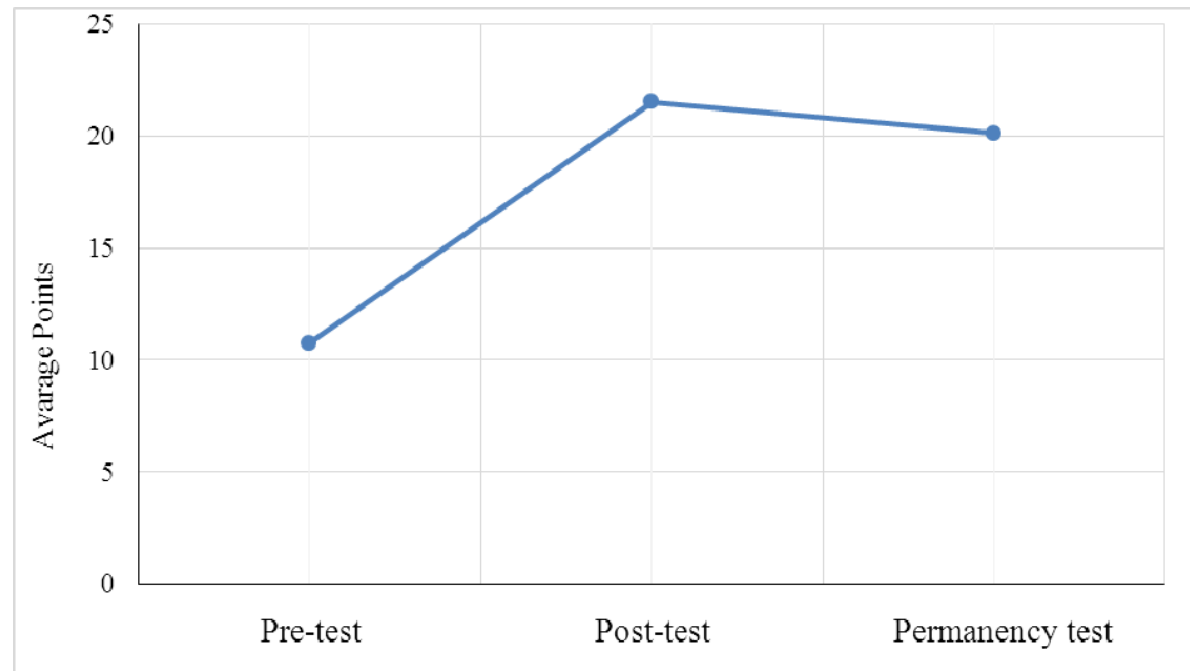

Figure 1. Athletes' pre-test-post-test-permanency test total scores

This finding can be interpreted as the success of the athletes who took winter mountaineering training changed significantly depending on the measurement. In addition, according to the eta square value, the effect of the training given on the success of the athletes in winter mountaineering is high (partial $\eta^{2 \text { nd }}=.811$ ). In the pairwise comparison (Bonferroni test) made to determine the difference between the measurements, it was determined that there was a significant difference between the pre-test and post-test scores and between the pre-test and permanency test scores $(\mathrm{p}<.05)$. Considering the averages, it is seen that this difference is in favor of the post-test. According to this finding, it can be said that winter mountaineering training has a positive effect on the success of the athletes. This situation appears in Figure 1.

In order to determine whether there is a significant difference among the pre-test, post-test and permanency test knowledge scores of the athletes who took winter mountaineering training. ANOVA test was performed for repeated measurements and test results are shown in Table 5. 


\section{Macrothink}

Table 5. Pre-test-post-test-permanency test knowledge scores of the research group related ANOVA results

\begin{tabular}{|l|l|l|l|l|l|l|l|}
\hline Source of Variation & Sum of Squares & $\mathrm{df}$ & Mean Squares & $\mathrm{F}$ & $\mathrm{p}$ & $\eta^{2}$ & S.D. Bonferroni \\
\hline Between group & & & & & & & \\
\hline Measurement & 2742.292 & 1.878 & 1460.485 & 369.568 & $.000^{*}$ & .780 & Pre-test-post-test \\
\hline Error & 771.708 & 195.276 & 3.952 & & & & \\
\hline Total & 3514 & 197.154 & 1464.437 & & & & \\
\hline
\end{tabular}

Note. $* \mathrm{p}<0.05 ; * * \mathrm{p}<0.01$.

When examined in Table 5, as the variances of the differences between the scores are not homogeneous and the epsilon value $(\varepsilon<0.75)$ was considered, analysis of variance including Greenhouse-Geisser correction was performed. According to the results of this analysis, there was a significant difference between the athletes' pretest-posttest-permanency test knowledge scores $\left(\mathrm{F}_{1.878-195.276}=369.568, \mathrm{p}<0.001\right)$. This finding can be interpreted as the knowledge level achievements of the athletes change significantly depending on the measurement. In addition, when the eta square value is examined, it has been determined that the effect of the training given on the knowledge level success of the athletes is high (partial $\eta^{2}=.780$ ). In the pairwise comparison made to specify the difference between the measurements, it was determined that there was a significant difference between the pre-test and post-test knowledge scores, and between the pre-test and permanency test knowledge scores $(p<.05)$. The difference between the post-test and permanency test knowledge scores was not significant. Pre-test score averages at the knowledge level of the athletes given winter training $\bar{x}=6.98$ in the last test while it increased to $\overline{\mathrm{x}}=13.42,4$ weeks later it is seen that it has decreased to $\overline{\mathrm{x}}=$ 13.05. As a result of the significant difference between the pre-test and post-test point averages at the level of knowledge, it can be said that the lessons taught are effective in ensuring the learning of the athletes. In addition, in the permanency measurements made later, it is seen that there is a slight decrease in the success scores of the athletes, but the effect of the training and practice continues. This situation appears in Figure 2. 


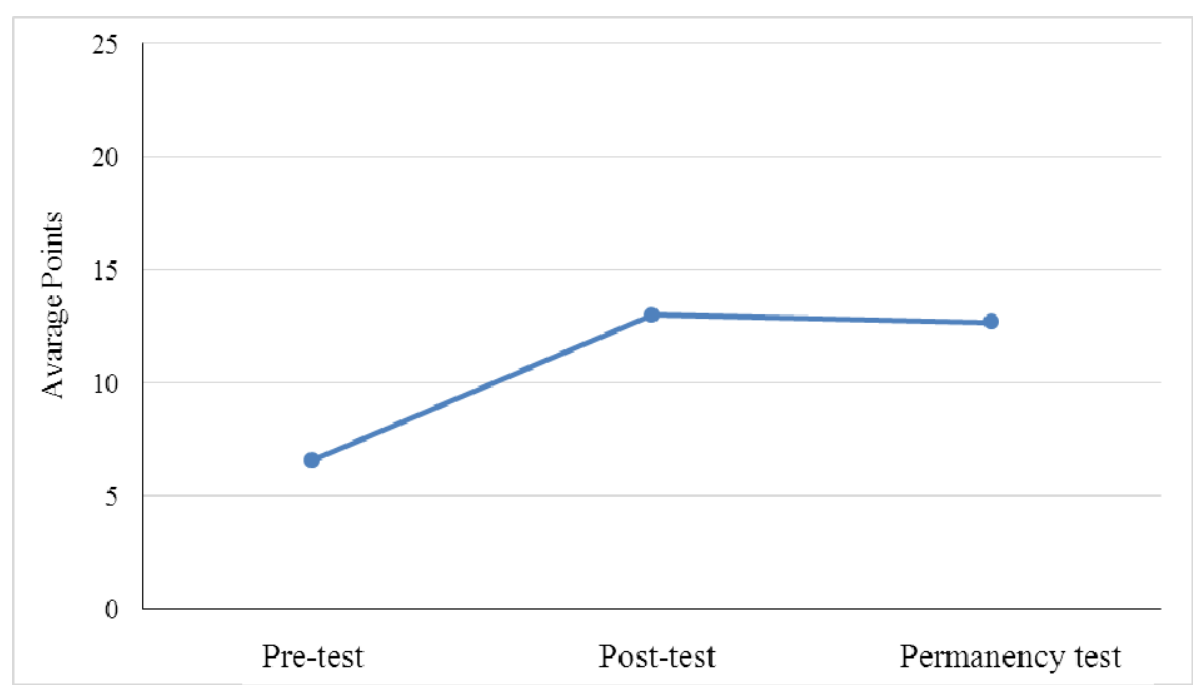

Figure 2. Athletes' total pre-test-post-test-permanency test knowledge scores

In order to determine if there is significant difference among the pre-test, post-test and permanency test practice scores of the athletes who took winter mountaineering training to repeated measurements ANOVA test was performed and test results are shown in Table 6.

Table 6. Pre-test post-test-permanency test practice scores of the research group related ANOVA results

\begin{tabular}{|l|l|l|l|l|l|l|l|}
\hline Source of Variation & Sum of Squares & $\mathrm{df}$ & Mean Squares & $\mathrm{F}$ & $\mathrm{p}$ & $\eta^{2}$ & S.D. Bonferroni \\
\hline Between groups & & & & & & & \\
\hline Measurement & 1343.511 & 1.740 & 772.171 & 286.035 & $.000 *$ & .733 & $\begin{array}{l}\text { Pre-post-test; } \\
\text { Pre-perm.-test }\end{array}$ \\
\hline Error & 488.489 & 180.951 & 2.700 & & & & \\
\hline Total & 1832 & 182.691 & 774.871 & & & & \\
\hline
\end{tabular}

Note. ${ }^{*} \mathrm{p}<0.05 ; * \mathrm{p}<0.01$

According to Table 6; the results of analysis of variance including Greenhouse-Geisser correction, the athletes; pretest-posttest-permanency test there was a significant difference between the practice level scores $\left(\mathrm{F}_{1.740-180.951}=286.035, \mathrm{p}<0.001\right)$. This finding can be interpreted as the practice level success of the athletes changed significantly depending on the measurement. Also, according to the assumed effect size measure value, it has been determined that the training given has a high effect (partial $\eta^{2}=.733$ ). on the success of the athletes' level of practice. In the pairwise comparison made to specify the difference between the 


\section{Macrothink

measurements, it was determined that there was a significant difference between the pre-test and post-test application scores and between the pre-test and permanency test application scores $(\mathrm{p}<.05)$. The difference between the post-test and permanency test application scores was not significant. Pre-test application point averages of the athletes was $\bar{x}=4.15$ and increased in the last test to $\bar{x}=8.53$ and weeks later it is seen that it has decreased to $\bar{x}=8.06$. As a result of the significant difference between the pre-test and post-test mean scores at the performance level, it can be said that the lessons taught are effective in ensuring the learning of the athletes. In addition, in the permanency measurements made later, it is seen that there is a slight decrease in the success scores of the athletes, but the effect of the training and practice continues. This situation appears in Figure 3.

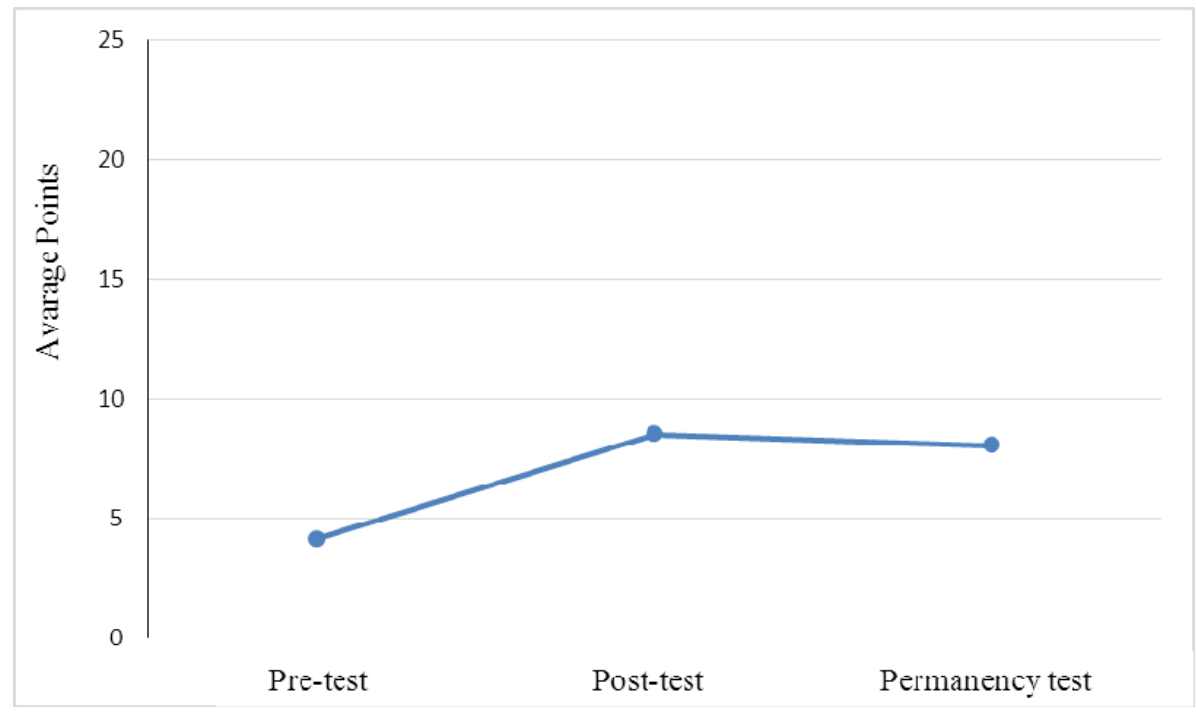

Figure 3. Total pre-test-post-test-permanency test practice scores

The gender variable of the pre-test, post-test, and permanency test total scores of the athletes who took winter mountaineering training. two-factor for repeated measurements to determine if there is a significant difference. ANOVA test was performed, and test results are shown in Table 5. 


\section{Macrothink}

Table 7. Pre-test-post-test-persistence test scores of the research group according to gender variable ANOVA results

\begin{tabular}{|l|l|l|l|l|l|l|l|}
\hline Source of Variation & Sum of Squares & df & Mean Squares & F & p & $\eta^{2}$ & S.D. Bonferroni \\
\hline Between groups & 22167.761 & 104 & & & & & \\
\hline Group (Female/Male) & 2.807 & 1 & 2.807 & 0.572 & 0.451 & .006 & - \\
\hline Error & 505.221 & 103 & 4.905 & & & & \\
\hline Within groups & 7077.548 & 197.777 & & & & & \\
\hline Measurement (Pre-post-permanency test) & 5237.478 & 1.866 & 2806.947 & 293.909 & $.000^{*}$ & .740 & Pre-post-test \\
\hline Measurement $\times$ Group & 4.602 & 1.866 & 2.466 & .258 & .757 & .003 & - \\
\hline Error & 1835.468 & 192.187 & 9.550 & & & & \\
\hline Total & 29245.309 & 301.777 & 2826.675 & & & & \\
\hline
\end{tabular}

Note. $* \mathrm{p}<0.05 ; * * \mathrm{p}<0.01$

When Table 7 is examined, it is seen that the total achievement scores of male and female athletes before and after the training do not differ significantly $\left(\mathrm{F}_{\text {Group }}=0.572, \mathrm{p}>.05\right)$. Regarding the achievements of winter mountaineering training, it is seen that there is a significant difference between the pre-, post- and permanency test average success scores $\left(F_{\text {Measurement }}=293.909, \mathrm{p}<.05\right)$. According to this finding, it can be interpreted that the winter mountaineering training achievement scores of all the athletes change depending on the teaching activities applied, without making any group distinctions.

Finally, it was found that the winter mountaineering training achievement scores of male and female athletes did not differ significantly from before to after the training, that is, the joint effects of repeated measurement factors on the success of my training were not significant $\left(\mathrm{F}_{\text {Measurement } \times \text { Group }}=.258, \mathrm{p}>.05\right)$. When the effect size values of my study were examined, .006 for between measurements .740 and finally for the group $\times$ measurement co-effect. were found. From these three values, it can be said that the effect between measurements has a high level of effect size.

In addition, in the pairwise comparison made to determine the difference between the measurements, it was determined that there was a significant difference between the pre-test and post-test scores $(\mathrm{p}<.05)$. Considering the averages, the pre-test $(\overline{\mathrm{x}}=10.76)$ and persistence test $(\overline{\mathrm{x}}=21.57)$ mean score of male athletes in the pre-test $(\overline{\mathrm{x}}=10.73)$, and persistence test $(\overline{\mathrm{x}}=$ $21.13)$ is higher than the mean score. This situation appears in Figure 4. 


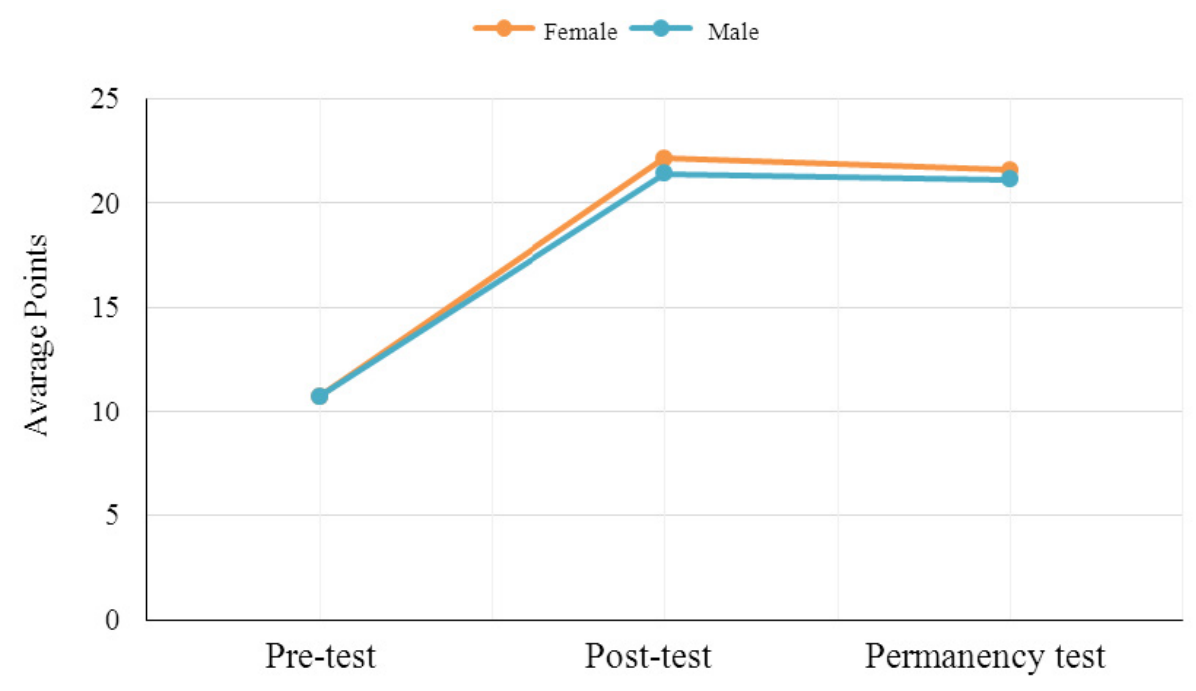

Figure 4. Pre-test-post-test-permanency test total scores of male and female athletes

\section{Discussion and Conclusion}

In this study, the effects of the winter mountaineering training given by the Turkish mountaineering federation on the success of the athlete and the permanency of learning were tried to be examined. In line with the findings obtained from the achievement test applied within the scope of the research, the following results were obtained and presented by discussing with the relevant literature.

There was a significant difference in athletes' participating in the study pretest-posttest and permanency test total scores. It was found that the success of the athletes who took winter mountaineering training changed significantly depending on the measurement; in other words, it has been concluded that the applied training program is an effective method in providing the desired gains to the athletes. Winter mountaineering is accepted to be a high-risk sport on routes with thin layers of ice on snow, ice, rock and under harsh conditions (Graydon \& Hanson, 2005) and needs high skill, a great willpower (Schoffl et al., 2010) and we can say it is very important to provide such gains in the research group.

In the literature, there are also studies that show similarities with the research findings (Demirhan, 1995; Aktas, 2006; Kangalgil \& Demirhan, 2013; Sural, 2015). Hebert and Landin (1994) conducted a study on tennis beginners and determined that there was a significant difference in the permanency test after the pre-test. Akınc1 (2004), in his research titled "the effect of dribbling and layup skills on learning and retention in basketball", pre-test and permanency test scores were found to be significantly higher. Tzetzis and Votsis (2006) examined the effect of acquisition and permanency after teaching two different difficulty skills in badminton and as a result of the research, it was stated that the effect on the acquisition and permanency of both skills would be great. Aktaş (2006), in his research titled "Learning the skills of the gymnastics unit in the 6th grade physical education lesson"; there was a statistically significant difference between the pretest-posttest and permanency scores. 
Ishikura (2008), in his study "investigating the effect of result knowledge rate on learning in golf swing without using visual feedback"; there is a significant difference as a result of the pretest-posttest and permanency test scores and this means they found that the error decreased in the post-test compared to the pre-test, and the error rate was lower in the permanency measurements. Kangalgil (2008) found that permanency and transfer scores had the highest scores in his study in which he examined the effects of different feedbacks given to students in physical education classes on achievement, permanency and transfer. In the study of Boyraz (2015), when the test was applied as a permanency test at the end of the six-month period, it was determined that the success level of the students in the entire experimental group was statistically significantly higher than the success level of the students in the control group. Yurtbaş1 (2019) in his research titled "physical education and sports lesson practices prepared with an interdisciplinary teaching approach"; a statistically significant difference was found between the pre-test and post-test scores of the students.

In addition, according to the results of the research, although it was determined that the success scores of male and female athletes through the training did not differ significantly, it was determined that there was a significant difference between the average success scores of the winter mountaineering training pre-test, post-test and permanency test. This result can be interpreted as the winter mountaineering training achievement scores of all the athletes, without making any group distinction, change depending on the applied teaching activities. Finally, it was found that the scores of the winter mountaineering training achievements of male and female athletes did not differ significantly through the training, in other words, the common effects of repeated measurement factors on the success of the training were not significant.

\section{References}

Akınc1, Y. (2004). Effect of Visual, Verbal, Visual+Verbal Feedback on Learning of Dribbling and Lay-up Skill (Unpublished Master thesis, The Graduate School of Social Sciences of METU, Ankara).

Aktaş, İ. (2006). The Effects of Verbal and Visual Feedback on Achievement and Permanency in Learning Forward, Backward and Handstand Somersault Skills in Elementary 6th Grade Gymnastics Unit (Unpublished Master thesis, Abant İzzet Baysal University Physical Education and Sports Teaching, Bolu).

Bashir, S., \& Muthueleckuvan, R. (2018). Effect of mountaineering training on selected physiological variable among moderate altitude inhabitants. International Journal of Physiology, Nutrition and Physical Education, 3(2), 720-722.

Boyraz, C. (2016). Science education based on games and physical activities: Interdisciplinary teaching practice (Doctoral dissertation, Anadolu University, Turkey).

Büyüköztürk, Ş. (2016). Data Analysis Handbook. Ankara: Pegem Academy Publishing.

Çokluk, Ö., Şekercioğlu, G., \& Büyüköztürk, Ş. (2012). Multivariate statistics for social sciences: SPSS and LISREL applications (Vol. 2). Ankara: Pegem Academy. 


\section{Macrothink

Demir, E. (2006). The Effect of Teaching Method with Concept Maps on Learning in Basketball and Badminton Units in Physical Education Lesson in 4th and 5th Grades in Primary Education (Unpublished Master thesis, Marmara University Institute of Educational Sciences, İstanbul).

Demirhan, G. (1995). The Effect of Student-Centered Method on Development and Permanency in Skill Learning in Sports (Unpublished $\mathrm{PhD}$ thesis, Hacettepe University, Institute of Social Sciences, Ankara).

Demirhan, G. (2003). Perception of Risk Related to Mountain Sports. Gazi Journal of Physical Education, 8(3), 3-10.

Graydon, D., \& Hanson, K. (2005). In T. Findik (Trans.), Freedom of Summits. Homer Bookstore and Publishing, İstanbul.

Hebert, P. H., \& Landin, D. (1994). Effects of a Learning Model and Augmented Feedback on Tennis Skill Acquisition. Research Quarterly for Excercise and Sport, 65(3), 250-257. https://doi.org/10.1080/02701367.1994.10607626

Ishikura, T. (2008). Reduced relative frequency of knowledge of results without visual feedback in learning a golf-putting task. Perceptual and Motor Skills, 106(1), 225-233. https://doi.org/10.2466/pms.106.1225-233

Kangalgil, M., \& Demirhan, G. (2013). The Effect of Types of Feedback Used in Physical Education Lessons on Reach and Permanency. Hacettepe University Faculty of Education Journal, 44, 189-197.

Korenjak, M. (2017). Why Mountains Matter: Early Modern Roots of a Modern Notion. Renaissance Quarterly, 70(1), 179-219. https://doi.org/10.1086/691833

Kurt, Ş., Bayazıt, B., Keskin, Ö., \& Taşkıran, M. Y. (2018). The effect of mountaineering education on social skills development of university students (Kocaeli University Example). Istanbul University Journal of Sport Sciences, 8(1), 1-10.

Lai, P. H., Hsu, Y. C., \& Wearing, S. (2016). A social representation approach to facilitating adaptive co-management in mountain destinations managed for conservation and recreation. Journal of Sustainable Tourism, 24(2), 227-244. https://doi.org/10.1080/09669582.2015. 1062018

Mirzeolu, D. E., Efe, F., \& Doğan, U. (2005). The Effect of 8th Grade Physical Education and Sports Lesson on Students' Cognitive and Psychological Achievements based on Active Learning Activities. Abant İzet Baysal University Journal of Social Sciences Institute, 2(11), 69-82. https://doi.org/10.11616/AbantSbe.143

Mohr, D. J., Townsend, J. S., \& Pritchard, T. (2006). Rethinking middle school physical education: combining lifetime leisure activities and sport education to encourage physical activity. Physical Educator, 63(1), 18-29.

Mummery, A. F. (2003). The Pleasures and Penalties of Mountaineering. In A. Weber (Ed.), 


\section{Macrothink}

Because It's There: A Celebration of Mountaineering from 200 B.C. to Today (pp. 225-240). Lanham: Taylor Trade.

Schoffl, V., Morrison, A., Schwarz, U., Schoffl, I., \& Kupper, T. (2010). Evaluation of injury and fatality risk in rock and ice climbing. Sports Medicine, 40(8), 657-679. https://doi.org/ 10.2165/11533690-000000000-00000

Siedentop, D., Hastie, P., \& Van der Mars, H. (2019). Complete guide to sport education. Human Kinetics.

Sural, V. (2015). The Effect of Basketball Lesson Taught with Different Teaching Methods on Students' Psychomotor Access Levels (pp. 45-88, Unpublished Master thesis, Institute of Educational Sciences, Ankara).

TDF. (2019). Turkish Mountaineering Federation Training Instruction. Retrieved August 25, 2021, from https://tdf.gov.tr/wp-content/uploads/2018/09/tdf-egitim-talimat\%c4\%b1-v11.pdf

Turgut, M. F., \& Baykul, Y. (2014). Assessment and Evaluation in Education (6th ed.). Ankara: Pegem Academy.

Tzetzis, G., \& Votsis, E. (2006). Three Feedback Methods in Acquisition and Retention of Badminton Skills. Perceptual and Motor Skills, 102(1), 275-284. https://doi.org/10.2466/pms. 102.1.275-284

UIAA (Union International des Associations d'Alpinisme). (2008). Retrieved from http://www.theuiaa.org

Yurtbaş1, Ö. (2019). Physical Education and Sports Lesson the Effect of Interdisciplinary Teaching Approach on Achievement, Attitude and Permanency" Example of 6th grade Science' Force and Movement Unit (Doctoral dissertation, Marmara University, İstanbul).

\section{Copyright Disclaimer}

Copyright for this article is retained by the author(s), with first publication rights granted to the journal.

This is an open-access article distributed under the terms and conditions of the Creative Commons Attribution license (http://creativecommons.org/licenses/by/3.0/). 